\title{
Comparison of drought stress indices in beech forests: a modelling study
}

Urša Vilhar

\section{Introduction}

Drought represents a weather-specific phenomenon that affects forests to vary ing extents and may result in a long-term decrease in forest productivity (Bergès \& Balandier 2010, Bertini et al. 2011) or forest decline (Wellpott et al. 2005, Bréda et al. 2006, Briceno-Elizondo et al. 2006, Anderegg et al. 2013b). Over the last 30 years, Europe has been affected by a number of major drought events, most notably in 1976 (Northern and Western Europe), 1989 and 1991 (most of Europe - Mishra \& Singh 2010). An extreme drought during the sum-

Slovenian Forestry Institute, Večna pot 2, 1000 Ljubljana (Slovenia)

@ Urša Vilhar (ursa.vilhar@gozdis.si)

Received: Mar 03, 2015 - Accepted: Dec 12, 2015

Citation: Vilhar U (2016). Comparison of drought stress indices in beech forests: a modelling study. iForest 9: 635-642. - doi: 10.3832/ifor1630-008 [online 2016-05-06]

Communicated by: Tamir Klein
Two drought stress indices were applied to managed as well as old-growth beech forests and gaps for the 2001 to 2013 period to aid in the development of an efficient tool for field water supply diagnosis. The relative extractable soil water (REW), which was calculated from the soil water content in the root zone, and the transpiration index $(\mathrm{TI})$, calculated as the ratio between the actual and potential transpiration were used. Both indices were calculated on a daily basis using the water balance model BROOK90, which was fitted and tested using measured data on throughfall and soil water content. A sensitivity analysis apportioned to the input parameters of the drought stress indices was conducted to assess uncertainty. Both drought stress indices showed the greatest drought stress in the years 2009, 2003 and 2011, as also indicated by the Standardized Precipitation Evapotranspiration Index (SPEI) at the nearest meteorological station. However, drought stress intensity and duration differed between the indices and study sites. Greater water supply stress was shown in the forests than the gaps. Furthermore, the agreement among the indices was smaller for gaps compared with forests, which implies that careful index selection is needed when comparing water supply stresses in different stages of forest stand development. Due to the low amount of input data required and the parameters that can be measured with relative ease in the field, REW might be an efficient tool for field water supply diagnosis when analyzing the drought stresses of similar forest types and at unique stages of development. REW satisfactorily indicated drought stress in forests but to a lesser extent in gaps. TI demonstrated more consistent differences in drought stress between forests and gaps and therefore proved to be the appropriate index for a detailed analysis of drought stress variation between different stages of forest stand development. However, due to a greater number of required input data and more demanding parameters, TI appears to be a more complex tool than REW for field water supply diagnosis in forests.

Keywords: Relative Extractable Soil Water, Transpiration Index, Standardized Precipitation Evapotranspiration Index, Fagus sylvatica, BROOK90 Model, Managed Forest, Old-growth Forest, Canopy Gap mer of 2003 led to broad disturbances in European forest ecosystems, which have et al. 2007, Nikolova et al. 2009, Lebourgeois et al. 2013, Sohn et al. 2013). Repeated droughts are assumed to be responsible for longer fire seasons, increased fire risk (Palahi et al. 2008) and widespread forest mortality (Bréda et al. 2006, Briceno-Elizondo et al. 2006, Anderegg et al. 2013a).

A drought index is usually the primary variable used to assess the effects of drought and to define drought parameters, which include intensity, duration, severity been reviewed by several authors (Granier

and spatial extent (Mishra \& Singh 2010). Most studies on water supply stress to date have focused on drought stress indices based on climate data (Mishra \& Singh 2010, Dogan et al. 2012). Some drought stress indices incorporate topographic and edaphic variability to assess fine-scale soil water availability (Dyer 2009, Piedallu et al. 2013). However, physiological indices, such as those related to soil water deficits (Zahner 1967) or transpiration rates (Zierl 2004, Wellpott et al. 2005), have been shown to be better correlated with radial growth and enable biological interpretations of vegetation responses to climate (Michelot et al. 2012, Tegel et al. 2014).

Currently, European beech (Fagus sylvatica L.) represents the most ecologically and economically important forest tree species presently supported by forest management in Slovenia (Kutnar \& Kobler 2011). However, the growth and competitive ability of beech may be adversely affected by climate change, particularly drought (Stojanović et al. 2013). Drought stress would be more likely to occur in shal- 
low soils such as those in this study. There have been several studies on water supply in canopy gaps (Ritter \& Vesterdal 2006, Dalsgaard 2007, Vilhar \& Simončič 2012) in which soil water availability influences forest regeneration and establishment (Gray \& Spies 1996, Madsen \& Hahn 2008, Vilhar et al. 2015). However, drought stress studies are scarce in old-growth forests, and some studies indicate differences in water supply stress between managed and oldgrowth forests at similar sites (Ritter 2004, Vilhar et al. 2005, Vilhar \& Simončič 2012).

The present study compared the performance of two drought stress indices that differed in structure and input data demand in beech forests on shallow soils in Slovenia. The study was carried out in a forest and a gap in an old-growth and a managed forest over a thirteen year period, thereby covering a range of environmental conditions likely to be encountered in Slovenian beech forests. An efficient drought stress index for field water supply diagnosis was sought. We applied (i) the relative extractable soil water (REW), which simulates water deficiency (the availability of soil water in the rooting zone - Bréda et al. 2006, Granier et al. 2007) and (ii) the actual and potential transpiration ratio (i.e., transpiration index, $\mathrm{TI}$ - Hammel \& Kennel 2001), that considers both atmospheric conditions and the properties and physiological processes of forests and their soils (Zierl 2001, Schwärzel et al. 2009a). Both REW and TI were compared with the Standardized Precipitation Evapotranspiration Index (SPEI - Vicente-Serrano et al. 2010), which is a climatic drought index, using precipitation and reference evapotranspiration at the nearest meteorological station. REW and TI were calculated on a daily basis using measured and modeled data with the water balance model BROOK90 (Federer 2002). We also investigated whether the water supply stress differed between the four sites. This was performed to demonstrate the effect of gap creation as a forest management practice on forest regeneration water supply stress (Vilhar et al. 2015). The comparison of selected drought stress indices should aid in the development of an efficient tool for field water supply diagnosis (Bergès \& Balandier 2010). Such a tool would enable forest managers to develop forest management strategies for adapting to climate change (Kolström et al. 2011).

\section{Methods}

\section{Site description}

The forests under investigation are located in southeastern Slovenia $\left(45^{\circ} 20^{\prime} \mathrm{N}\right.$, $14^{\circ} 30^{\prime} \mathrm{E}$, elevation 860-890 $\mathrm{m}$ a.s.l.). They belong to the Omphalodo-Fagetum association (Puncer 1980), which is dominated by silver fir (Abies alba Mill.) and European beech (Fagus sylvatica L.). Norway spruce (Picea abies [L.] Karst.), maple (Acer pseudoplatanus L.), elm (Ulmus glabra Huds.), and lime (Tiliacordata Mill.) make up less than $1 \%$ of the total stem volume (Vilhar et al. 2015). The bedrock consists of Cretaceous limestone, and the soil depth varies from 10 to $40 \mathrm{~cm}$ depending on the highly variable karstic micro-relief. The prevailing soil units were Eutric Cambisols and Rendzic Leptosols (Urbančič et al. 2005). The climate of the region is montane with an annual precipitation of up to $1600 \mathrm{~mm}$. The nearest meteorological station, Kočevje $\left(45^{\circ} 39^{\prime} \mathrm{N}, 14^{\circ} 51^{\prime} \mathrm{E}, 467 \mathrm{~m}\right.$ a.s.l.), has recorded a long-term (1971-2000) annual average air temperature of $8.0^{\circ} \mathrm{C}$ and annual precipitation of $1481 \mathrm{~mm}$ (Environmental Agency of the Republic of Slovenia archives). Based on this value and an environmental lapse rate of $6{ }^{\circ} \mathrm{C}$ per $\mathrm{km}$ of elevation, the long-term annual average temperature at the study area is $5.9^{\circ} \mathrm{C}$ (Vilhar et al. 2006b).

The specific old-growth and managed forests in this study have similar elevation, aspect and slope. In the old-growth forest, an irregular-shaped gap was formed after windstorms during the winter of 2002-2003 (Tab. 1). In the managed forest, an irregular experimental clear-cut gap was created in the winter of 2000-2001. All of the trees in the experimental gap were harvested and carefully removed by horse skidding.

\section{Meteorological data and soil} hydrological measurements Meteorological data were collected above the tree crowns using an automatic weather station (Vantage $\operatorname{Pro}^{\circledast}$ wireless, Davis Instruments, Hayward, California, USA). Hourly average values of air temperature and humidity, wind direction and speed, and sums of precipitation were recorded (Vilhar et al. 2006b). Missing air temperature and humidity data were substituted with data from the Kočevje meteorological station, and missing global radiation data were substituted with data from the Iskrba EMEP station (Environmental Agency of the Republic of Slovenia archives) using site-specific regression functions (Vilhar et al. 2006b). In the years 2001 to 2007 , monthly or biweekly precipitation (throughfall) was recorded in the forests and gaps at a height of $1.3 \mathrm{~m}$ using a series of nine funnel collectors (240 $\mathrm{cm}^{2}$ each) arranged along a regular grid (spacing: $5 \times 5$ $\mathrm{m})$. Incidental precipitation was recorded monthly in the years 2001 to 2007 in an open field close to the study sites using the same type of funnel collectors. For the oldgrowth gap, which had naturally formed during the winter of 2002-2003, datasets from the years 2003 to 2007 were used.

Using representative soil samples taken from the prevailing soil units, the available water capacity of the mineral soil horizons was calculated for each site from pressure plate measurements of field capacity (moisture content at $0.033 \mathrm{MPa}$ ). The permanent wilting point (moisture content at 1.5 MPa) and saturated soil hydraulic conductivity were also determined. The average soil thickness at all sites was $40 \mathrm{~cm}$, and this depth was assumed to be the rooting depth for all sites. The soil water content (SWC) of the $0-40 \mathrm{~cm}$ layer was measured monthly at three locations in each plot in 2003 and twice monthly from 2004 to 2007 using time domain reflectometry (TDR - Prenart Equipment, Frederiksberg, Denmark). Double probes were installed vertically, extending through the $40 \mathrm{~cm}$ layer, and included the organic layer. Soilspecific calibration curves for vertical TDR probes were used and were obtained using the calibration procedures described in Dirksen (1999). During 2001 and 2002, SWC was determined once per month by taking three replicate volumetric soil samples at

Tab. 1 - General characteristics of the study sites.

\begin{tabular}{lllll}
\hline \multirow{2}{*}{ Parameter } & Managed & & Old-growth & \\
\cline { 2 - 5 } & Forest & Gap & Forest & Gap \\
\hline Stem volume $\left(\mathrm{m}^{3} \mathrm{ha}^{-1}\right)$ & 255 & - & 746 & - \\
\hline Basal area $\left(\mathrm{m}^{2} \mathrm{ha}^{-1}\right)$ & 17 & - & 49 & - \\
\hline Year of creation & - & 2000 & - & 2003 \\
\hline Shape and dimensions & - & Near-circular, $2375 \mathrm{~m}^{2}$ & - & Irregular, $710 \mathrm{~m}^{2}$ \\
\hline Harvesting method & - & Experimental clear-cut & - & Windstorms \\
\hline Forest floor vegetation - dominant species & Dryopteris filix-mas, Lamium orvala, & Fagus sylvatica & \\
& Polystichum aculeatum & & 62 \\
\hline Ground vegetation cover (\%) & 20 & 6 & 22 & 29.9 \\
\hline Soil depth $(\mathrm{cm})$ & 32.2 & 31.3 & 32.6 & 23.1 \\
\hline Stoniness $(\%$ vol) & 24.4 & 22.3 & 29.7 & Clay loam \\
\hline Soil Texture class & Loam & Loam & Clay loam & \\
\hline
\end{tabular}


depths of 10,20 , and $40 \mathrm{~cm}$ in each plot and by measuring the weight loss after oven drying the samples at $105^{\circ} \mathrm{C}$ for $24 \mathrm{~h}$. The volumetric moisture contents were converted into depths of water $(\mathrm{mm})$ by multiplying the values by the thickness of the soil layer and correcting for stone content.

\section{The BROOK9o simulation}

The water balance model BROOK9o Version 4.4g (Federer 1995, Hammel \& Kenne 2001, Federer et al. 2003) was applied to forests and gaps to simulate the input parameters needed for the REW and TI calculations. The model calculates daily water fluxes (tree transpiration, evapotranspiration, interception, throughfall, soil evaporation, drainage) and SWC at different depths or for the whole rooting depth. Tree transpiration and soil evaporation are calculated separately using the Shuttleworth-Wallace method (Shuttleworth \& Wallace 1985) modified to separate daytime from night time evaporation (Federer 1995). Model parameterisation for the study sites is described in detail by Vilhar 8 Simončič (2012).

The interception model was fitted by comparing the simulated and the measured monthly throughfall (TF) for the managed and old-growth forest from 2001 to 2003 and tested with the TF from 2004 to 2007. Additional model fitting was performed by comparing the simulated and measured daily SWC of the rooting zone (corrected for stone content) for forests and gaps using datasets from 2001 to 2004 and tested with datasets from 2005 to 2007. For the old-growth gap, which had naturally formed during the winter of 2002 2003, datasets from 2003 to 2007 were used. The extent of TF and SWC fit was evaluated by examining the linear correlation coefficient ( $r$ ), which describes the degree of correspondence between the measured and simulated values; the index of agreement (D - Thompson 1999), which describes relative error; and the root mean square error (RMSE), which expresses the error between the measured and simulated values.

\section{Drought stress indices}

\section{Relative extractable soil water (REW)}

The relative extractable soil water (REW) indicates the availability of soil water in the rooting zone. As a simple drought stress index, the REW may be computed from soil water content in the root zone at any given time, as follows (Bréda et al. 2006, Granier et al. 2007 - eqn. 1):

$$
R E W=\frac{S W C_{d a y}-S W C_{\min }}{S W C_{\max }-S W C_{\text {min }}}
$$

where $S W C_{\text {day }}$ is the daily soil water content $(\mathrm{mm})$, whereas $S W C_{\min }$ and $S W C_{\max }$ are the minimum and maximum soil water content $(\mathrm{mm})$ for the entire rooting zone during the period of interest. The REW is between 1.0 (maximum soil water content) and o (minimum soil water content). In the present study, the daily REW values for forests and gaps were calculated from the simulated daily SWC during the growing season (i.e., May to October) from 2001 to 2013 (with the exception of the natural gap from 2003 to 2013), using the BROOK90 model. For the REW calculation, the daily $S W C_{\min }$ and $S W C_{\max }$ for the entire modeling period were used. Because a site-specific critical value of the matrix potential was not available for the assessment of the soil water deficits, water supply stress was assumed to occur when the REW dropped below the threshold of $0.4\left(R^{2} W_{c}\right)$, thereby inducing stomatal regulation in forest trees (Granier et al. 1999). Although Lagergren \& Lindroth (2002) report on slightly lower REW threshold values for pine and spruce trees in Sweden, the threshold of REW < 0.4 has been widely used in different forest ecosystems (Bréda et al. 2006, Granier et al. 2007, Michelot et al. 2012, Zhou et al. 2013). Additionally, the duration of the water supply stress, i.e., the percentage of growing season days with an REW below $0.4\left(R W_{c}\right)$ for forests and gaps was calculated to quantify the duration of the water supply stress (Bréda et al. 2006).

\section{Transpiration index ( $\mathrm{TI})$}

The transpiration index $(\mathrm{TI})$ is a daily ratio between simulated actual and potential transpiration. $\mathrm{Tl}$ is a more complex drought stress indicator than REW because measurements of transpiration rates in forest ecosystems using the sap flow measurements of single trees and scaling up to forest stands (as in $\mathrm{TI}$ ) are costly and time consuming (Granier \& Loustau 1994, Cermák et al. 2004). Therefore, the mathematical modeling of transpiration rates has become an alternative approach in daily determinations of the seasonal variation of transpiration in forest trees (Granier et al. 2000, Matejka et al. 2007). In the present study, daily $\mathrm{TI}$ values for forests and gaps were calculated from simulated actual and potential transpiration during the growing season using the BROOK9o model from 2001 to 2013, with the exception of the natural gap from 2003 to 2013 . Potential transpiration in the BROOK9o model is defined as the theoretical transpiration rate that would occur if the soil-plant system was able to satisfy the atmospheric demand and the stomatal regulation was unaffected by drought stress (Federer 1995). Actual transpiration, by contrast, is defined as the actual transpiration rate with stomatal opening adapted to the current drought stress conditions. A TI equal to 1 indicates that the water supply of the forest is optimal, whereas a TI value of less than 1 indicates temporary water deficiency (Wellpott et al. 2005). Hammel \& Kennel (2001) defined sites as having frequent water deficiency when the $25^{\text {th }}$ percentile of their daily TI values was below 0.95. Schwärzel et al. (2009a) reported that transpiration in beech stands was significantly reduced when the daily actual transpiration was < $70 \%$ of the daily potential transpiration $(\mathrm{TI}<$ 0.7). Therefore, the percentage of days with a TI below the critical threshold of 0.7 $\left(\mathrm{TI}_{\mathrm{c}}\right)$ for each growing season was calculated to quantify the duration of water supply stress.

\section{Standardized Precipitation}

Evapotranspiration Index (SPEI)

The Standardized Precipitation Evapotranspiration Index (SPEI - Vicente-Serrano et al. 2010) is a climatic drought index that indicates general water supply for a study area. The SPEI may be calculated using monthly (or weekly) precipitation and grass reference evapotranspiration at the nearest meteorological station as follows (eqn. 2):

$$
S P E I=P_{i}-R_{e f} E_{T}
$$

where $P_{i}$ is monthly (or weekly) precipitation and Ref ETP $P_{i}$ is grass reference evapotranspiration, which is calculated using the FAO-56 Penman-Monteith equation (Allen et al. 1998, Vicente-Serrano et al. 2010). The SPEI varies between maximum precipitation (when Ref ETP is zero) and reaches negative values when Ref ETP $P_{i}$ exceeds the precipitation amount, indicating a negative climatic water balance on a monthly basis. In the present study, the monthly SPEI was calculated from P and Ref ETP data at the Kočevje meteorological station (Environmental Agency of the Republic of Slovenia archives) and compared with monthly REW and $\mathrm{TI}$ for forests and gaps. Additionally, the percentage of days with a negative climatic water balance (SPEI < 0.0) for each growing season from 2001 to 2013 was calculated to quantify the duration of the negative climatic water balance in the study area.

\section{Statistical analyses}

Due to a non-normal distribution, the Spearman's rank correlation coefficient $(R)$ was used to evaluate the relationship between the daily REW and $\mathrm{TI}$ in forests and gaps. Differences between REW and TI at each site were assessed using the Kruskal-Wallis test. Probability values of $p<$ $0.05\left(^{*}\right), \mathrm{p}<0.01\left(^{* *}\right)$ and $\mathrm{p}<0.001(* * *)$ were considered significant. The data analysis was performed using the software package Graphpad $^{\oplus}$ (Graphpad 2014).

\section{Results}

The results of this study clearly demonstrate significantly greater simulated daily SWC in gaps compared with forests during the growing seasons 2001-2013 $(\mathrm{H}=5615$, $\mathrm{df}=3, \mathrm{~N}=9200, \mathrm{p}<0.001-$ Fig. 1a). Furthermore, the simulated daily actual transpiration significantly differed between all sites over the course of the study period $(\mathrm{H}$ $=-486.6, \mathrm{df}=3, \mathrm{~N}=9200, \mathrm{p}<0.001)$ with higher average seasonal values in the 


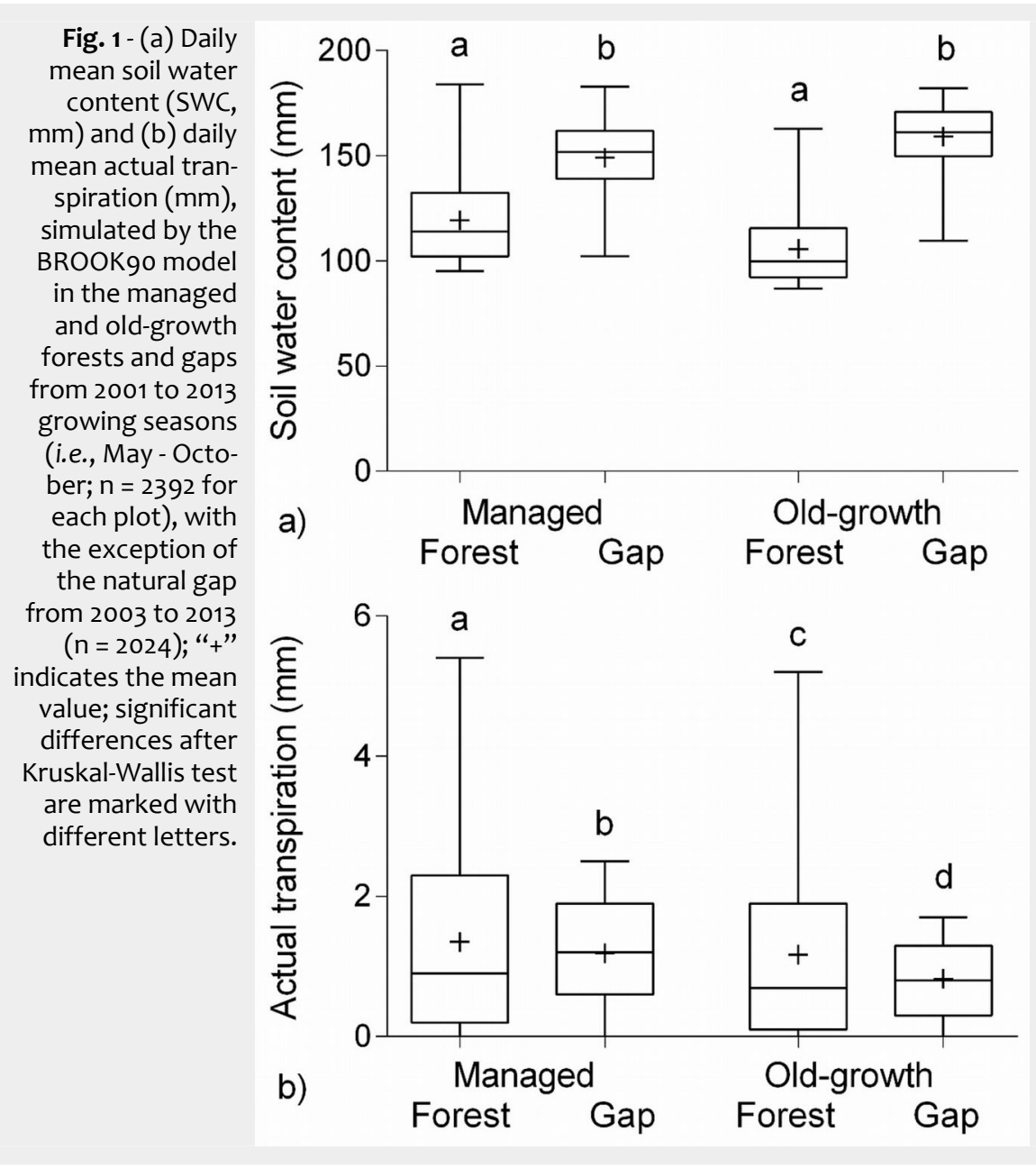

forests than the corresponding gaps (Fig. 1b).

\section{BROOK9o model fitting and testing}

Tab. S1 in Supplementary Material summarises the input parameters used in the simulations. Monthly TF and daily SWC were accurately simulated in the BROOK90 model in respect to both time and magnitude for all sites. The average D was 0.881 and the average RMSE was 11.8 for the SWC model fitting; the average $D$ was 0.754 and the average RMSE was 16.1 for model testing (Tab. S2 and Fig. S1 in Sup plementary Material). For TF, the average D for model fitting was 0.823 and average RMSE was 49.4; for model testing, the average $D$ was 0.752 and average RMSE was 78.1 (Tab. S3 and Fig. S2 in Supplementary Material).

\section{Drought stress indices}

The daily average air temperature in the period from 1971 to 2000 at the Kočevje meteorological station was $8.0^{\circ} \mathrm{C}$ with a minimum in January $\left(-1.3^{\circ} \mathrm{C}\right)$ and maximum in July $\left(17.5^{\circ} \mathrm{C}\right)$. The daily average air temperature for the study period from 2001 to 2013 at the Kočevje meteorological station was $9.2{ }^{\circ} \mathrm{C}$, with the highest daily air temperature reported in $2002\left(9.7 \pm 7.4^{\circ} \mathrm{C}\right)$ and $2007\left(9.7 \pm 7.3^{\circ} \mathrm{C}\right)$ and the lowest in 2005 $\left(8.1 \pm 8.5^{\circ} \mathrm{C}\right)$. The average annual precipita- autumn months. The drought stress indices showed the greatest drought stress in the growing seasons of 2003, 2009 and 2011; however, the drought stress intensity and duration differed between indices and study sites. According to REW, drought stress was most intense in 2009 at all sites with the exception of the old-growth site with a maximal number of days with REW < REW $_{c}$ in 2006 (Fig. 2). Longer drought spells in both forests were also indicated in 2011 and 2008, when the number of days with REW $<$ REW $_{c}$ was more than $88 \%$ of the days in the growing season. TI indicated the greatest drought stress in the managed forest in 2003 and the managed gap in the 2006 growing season. In the oldgrowth forest, the greatest drought stress according to TI was in 2011; however, the maximal number of days with $\mathrm{TI}<\mathrm{TI}_{\mathrm{c}}$ occurred in 2003 ( $59 \%$ of days in the growing season). For the old-growth gap, however, the greatest drought stress according to TI was in 2013 but the maximal number of days with $\mathrm{TI}<\mathrm{TI}_{\mathrm{c}}$ occurred in 2012 (39\% of days in the growing season).

Both REW and TI indicated significantly greater drought stress in forests than gaps (REW H $=4283.8, \mathrm{TI} \mathrm{H}=327.5, \mathrm{df}=3, \mathrm{~N}=$ $9200, p<0.001$ - Fig. 3). Furthermore, slightly greater drought stress was shown for the old-growth forest by both indices compared with managed forest. Nevertheless, REW indicated greater and $\mathrm{TI}$ minor drought stress in the managed compared with old-growth gap. As a consequence, the number of days with $\mathrm{TI}<\mathrm{TI}_{\mathrm{c}}$ indicated a similar difference in drought stress duration between forests and gaps ( $25 \%$ in managed and $23 \%$ in old-growth sites), whereas the number of days with REW $<\mathrm{REW}_{c}$ indicated larger differences in the old-growth (70\%) compared with managed sites (55\%).

Daily values of both indices were in good agreement between the forests (REW R = 0.995 , TI $R=0.949 ; p<0.05$ ) as well as between the gaps (REW R $=0.898$, TI R = 0.882; $p<0.05$ ). However, there was slightly lower agreement in daily REW or TI between forests and gaps (daily REW between the managed forest and gap: $R=$ 0.638 , daily $\mathrm{TI} R=0.789$; daily $\mathrm{REW}$ between the old-growth forest and gap: $R$ $=0.679$, daily TI $R=0.657 ; p<0.05$ ).

When comparing the drought stress intensity at all sites, we found significant differences between the daily REW and TI $(\mathrm{H}=733.2, \mathrm{df}=1, \mathrm{~N}=5486, \mathrm{p}<0.001)$, as well as between the days below REW $c$ and those below $\mathrm{TI}_{\mathrm{c}}(\mathrm{H}=2039.9, \mathrm{df}=1, \mathrm{~N}=$ 9200, $\mathrm{p}<0.001)$. Nevertheless, the agreement between the days below $\mathrm{REW}_{c}$ and those below $\mathrm{Tl}_{\mathrm{c}}$ was slightly higher $(\mathrm{R}=$ $0.591)$ than the agreement between the REW and $\mathrm{TI}(\mathrm{R}=0.567, \mathrm{p}<0.05)$, respectively. There was a better agreement between daily REW and TI for the oldgrowth $(R=0.831)$ and managed forests ( $R=0.815, p<0.05)$ than between REW and TI for the gaps $(R=0.574$ for the managed gap, $R=0.503$ for the old-growth 
Fig. 2 - The number of days with a Standardized Precipitation Evapotranspiration Index below $0.0(\mathrm{SPEI}<0.0)$ at the Kočevje meteorological station. (a) The number of days with a relative extractable water content below 0.4 (REW < REW , \%) and (b) the number of days with a transpiration index below $0.7(\mathrm{TI}$ $\left.<\mathrm{TI}_{\mathrm{c}}, \%\right)$ for the managed and old-growth forests and gaps for the 2001 to 2013 growing seasons (i.e., May - October), with the exception of the natural gap from 2003 to 2013 .

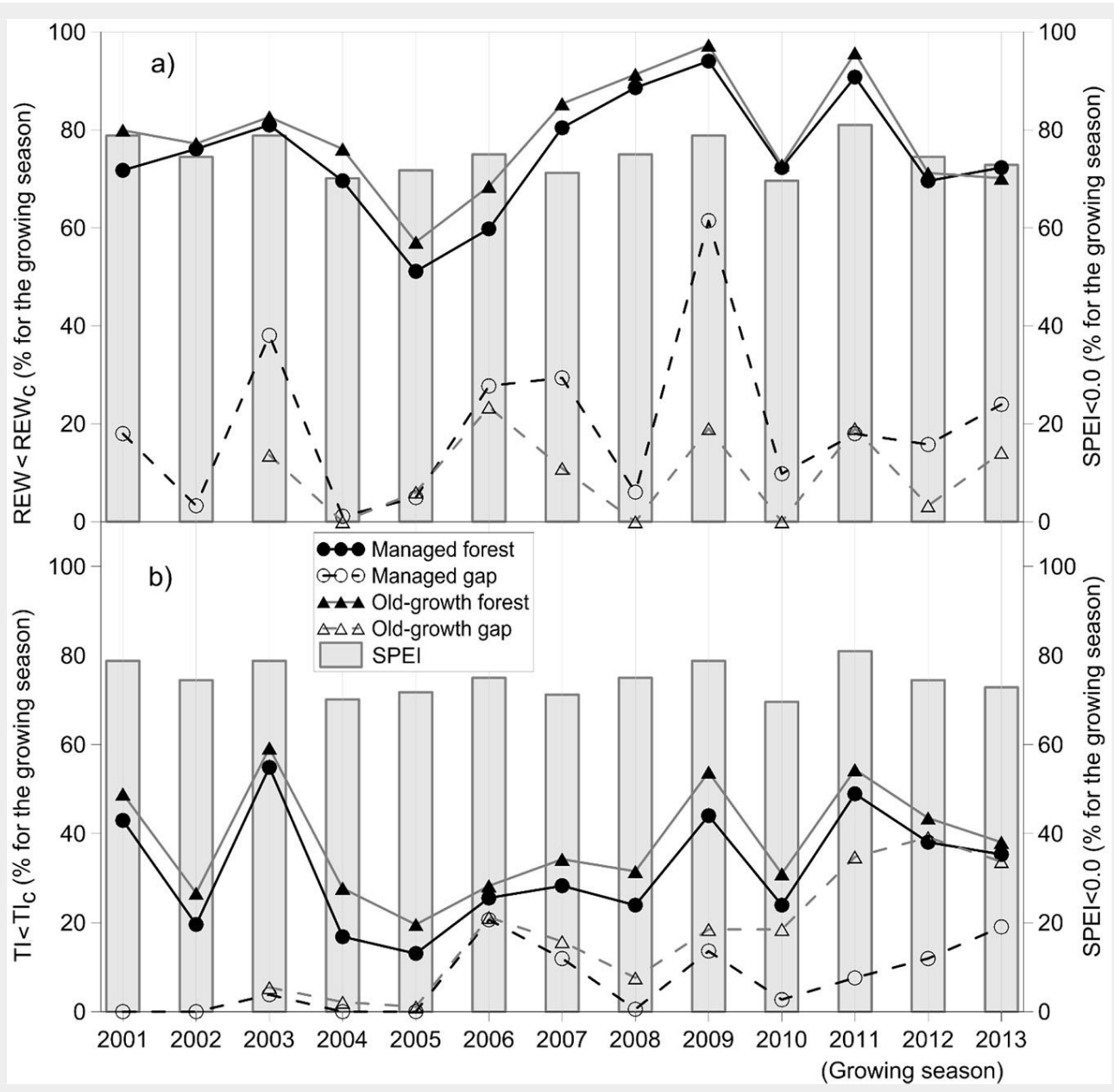

gap; $\mathrm{p}<0.05$ ). The agreement between the days below REW and those below $\mathrm{TI}_{\mathrm{c}}$ was better in the managed compared with oldgrowth sites $(R=0.749$ for the managed gap, $R=0.509$ for the managed forest, $R=$ 0.480 for the old-growth gap and $R=0.461$ for the old-growth forest; $p<0.05$ ).

A comparison of the monthly SPEI at all sites with the REW and TI showed statistically significant differences $(\mathrm{H}=85.0, \mathrm{df}=$ $2, \mathrm{~N}=978, \mathrm{p}<0.001)$. However, the agreement between SPEI and TI was slightly higher $(R=0.461)$ than between the SPEI and REW $(R=0.402, p<0.001)$. Additionally, the difference between the SPEI $<0.0$ and the number of days with REW $<\mathrm{REW}_{\mathrm{c}}$ or $\mathrm{TI}<\mathrm{TI}_{c}$ was statistically significant $(\mathrm{H}=$ $270.8, \mathrm{df}=2, \mathrm{~N}=978, \mathrm{p}<0.001)$. The agreement was higher between the number of days with SPEI $<0.0$ and days with $\mathrm{TI}<\mathrm{Tl}_{\mathrm{c}}$ $(R=0.513)$ than between the number of days with SPEI $<0.0$ and the days with REW $<\operatorname{REW}_{c}(\mathrm{R}=0.416, \mathrm{p}<0.001-$ Fig. 4). Regarding the sites, the highest agreement between SPEI and REW was found in the managed forest $(R=0.582)$ and gap $(R=$ $0.546)$, followed by the old-growth forest $(\mathrm{R}=0.491)$ and gap $(\mathrm{R}=0.483, \mathrm{p}<0.001)$. However, the agreement between the number of days with SPEI $<0.0$ and days with REW $<$ REW $_{c}$ was highest in the oldgrowth forest $(R=0.607)$, followed by the managed forest $(R=0.580)$, managed gap $(R=0.578)$ and old-growth gap $(R=0.505$, $p<0.001)$. The highest agreement be- whereas the agreement was not significant tween SPEI and TI was found in the old- for the gaps. The agreement between the growth forest $(R=0.675)$ followed by the number of days with SPEI $<0.0$ and the managed forest $(R=0.631, p<0.001)$, days with $\mathrm{TI}<\mathrm{Tl}_{\mathrm{c}}$ was highest in the man-

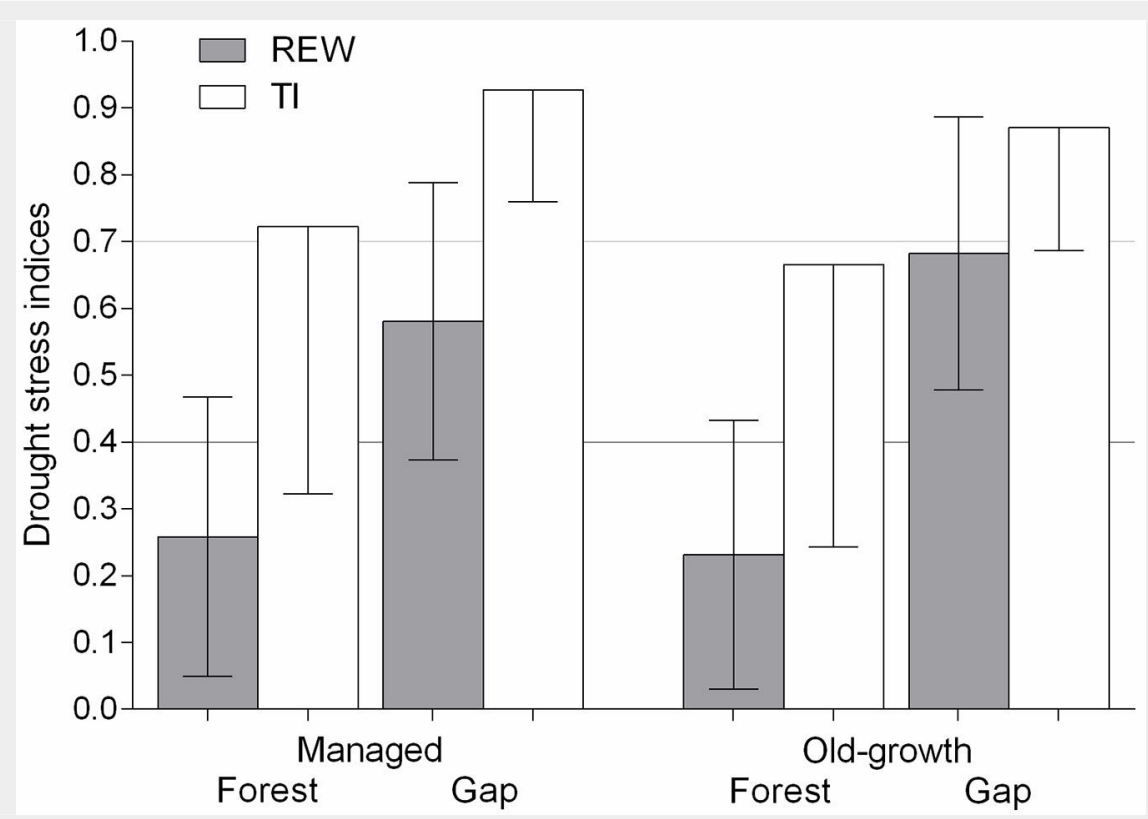

Fig. 3 - Daily mean relative extractable soil water (REW) and transpiration index ( $\mathrm{TI})$ in the managed and old-growth forests and gaps from 2001 to 2013 growing seasons (i.e., May - October), with the exception of the natural gap from 2003 to 2013. REW and $\mathrm{TI}$ equaling 1 indicate no drought stress. 
Fig. 4 - Comparison of monthly percentage of days with a Standardized Precipitation Evapotranspiration Index below 0.0 (SPEI < 0.0, \%) at the Kočevje meteorological station and a) the number of days with the relative extractable water content below 0.4 (REW < REWc, \%) and $b$ ) the number of days with the transpiration index below 0.7 ( $\mathrm{TI}$ $<\mathrm{TIC}$ \%) in the managed and old-growth forests and gaps from 2001 to 2013 growing seasons (i.e., May - October), with the exception of the natural gap from 2003 to 2013 . The line is the regression line for all sites $(n=300)$.

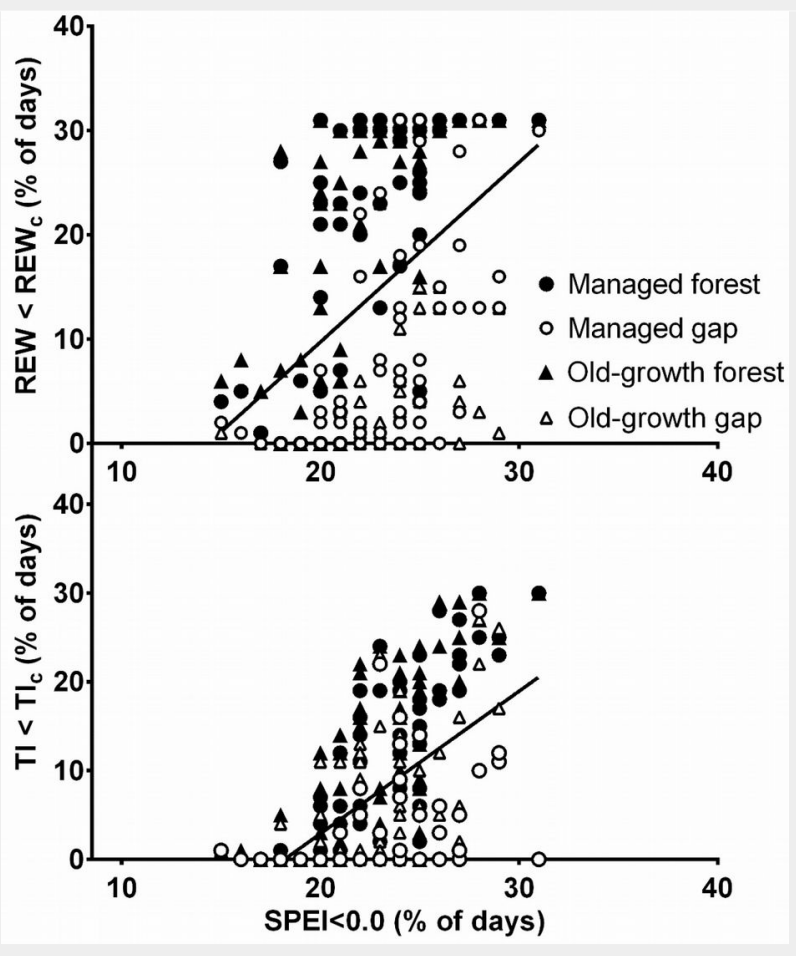

aged $(R=0.715)$ and old-growth forests $(R$ $=0.700)$, followed by the old-growth $(R=$ $0.479)$ and managed gap $(R=0.424, p<$ $0.001)$.

\section{Discussion}

Both drought stress indices showed the greatest drought stress in the years 2009, 2003 and 2011, as also indicated by the SPEI at the nearest meteorological station. However, drought stress intensity and duration differed between indices and study sites. Both $\mathrm{TI}$ and REW showed greater drought stress in forests than gaps in managed as well as old-growth forests. Higher Spearman rank coefficients indicated a better agreement between daily REW and $\mathrm{TI}$ for the forests than for the gaps, implying that indices should be carefully selected when comparing water supply stress between different stages of forest stand development.

According to REW, the greatest and longest drought stress in all sites occurred in 2009, followed by the 2001 growing season. $\mathrm{Tl}$ indicated the greatest and longest drought stress in 2011, followed by the 2003 and 2009 growing seasons. TI was more strongly correlated with the SPEI than REW but only for the forests. The SPEI and TI were not significantly correlated for the gaps.

Both indices ( $\mathrm{TI}$ and REW) showed a greater water supply stress for the forests than for the gaps, which is in accordance with previous studies (Vilhar et al. 2005, Vilhar \& Simončič 2012). Due to lower interception and lower transpiration (CognardPlancq et al. 2001, Zirlewagen \& Von Wilpert 2001), plants in the gaps benefit from higher precipitation input and increased soil water storage compared with the sur- rounding forest (Gray et al. 2002, Ritter \& Vesterdal 2006, Dalsgaard 2007). However, REW indicated larger differences in drought stress duration between forests and their corresponding gaps (55-70\%); similar differences were found via $\mathrm{TI}$ (23-25\%). The REW calculation is based on the daily, minimum and maximum SWC for the measurement period, which can be derived from modeled data or from continuous SWC profile measurements (Schwärzel et al. 2009b). Such measurements are currently cost-effective (Ferlan \& Simončič 2012) and can be numerously installed in larger forest areas. However, a sensitivity analysis revealed that REW is sensitive to both minimum and maximum SWC for the measurement period. Furthermore, REW satisfactorily indicated drought stress in forests but to lesser extent in gaps. Due to the low amount of required input data as well as parameters that can be measured in the field with relative ease, REW may be an efficient tool for field water supply diagnosis (Bergès \& Balandier 2010) when analyzing the drought stress of similar forest types and at unique stages of development.

TI demonstrated more consistent differences between forests and gaps in regard to drought stress in different stages of forest stand development. TI is a more complex drought stress indicator than REW. Measurements of actual and potential transpiration rates in trees are costly and time consuming (Granier \& Loustau 1994, Cermák et al. 2004). Potential transpiration rates in forest trees are also difficult to measure; however, some studies have reported on the transpiration rates of trees under non-limiting soil water conditions (Cermák et al. 1982, 1993, Cienciala et al.
1994, Granier et al. 2000). Transpiration rates of forests are therefore often simulated using complex water balance models (Granier et al. 2000, Vilhar et al. 2006a, Matejka et al. 2007) with greater input data requirements (Hammel \& Kennel 2001). The actual and potential transpiration in the BROOK9o model can be controlled using a number of parameters related to the tree stand, including tree height, leaf water potential, soil matrix potential, inner plant resistance, and others. However, the better performance of $\mathrm{Tl}$ is associated with a substantial increase in the need for input data and parameters compared with REW. Daily meteorological data as well as parameters describing the site, the canopy, the soil and the water flow through the soil are required. Many of these parameters are rarely measured in the field and are often obtained from the literature. Thus, TI may provide more accurate estimates of drought stress in different forest types and stages of forest stand development; however, due to the greater number of required input data and parameters, $\mathrm{Tl}$ also appears to be a less efficient tool for field water supply diagnosis in forests.

Further research on site-specific REW and TI thresholds is needed, as well as the integration of drought stress indicators with forest reactions, e.g., crown defoliation (Zierl 2004) or increment losses (Michelot et al. 2012, Tegel et al. 2014) for beech forests in Slovenia.

\section{Conclusions}

Both the relative extractable soil water (REW) and the transpiration index ( $\mathrm{TI}$ ) indicated the greatest drought stress in the years 2009, 2003 and 2011, as also shown by the SPEI at the nearest meteorological station.

Both indices ( $\mathrm{TI}$ and REW) showed greater water supply stress for the forests than for the gaps in managed as well as old-growth forests. However, REW indicated larger differences in drought stress duration between forests and their corresponding gaps (55-70\%), whereas for TI differences between forests and corresponding gaps were smaller (23-25\%).

REW may be an efficient tool for field water supply diagnosis when analyzing the drought stress of similar forest types and at unique stages of development due to the low amount of required input data.

$\mathrm{TI}$ proved to be an appropriate index for the detailed analysis of drought stress variation in different forest types and stages of forest stand development. However, due to more complex measurements or the mathematical modeling of transpiration rates in forest ecosystems, TI also appears to be a more complex tool for field water supply diagnosis in forests compared to REW.

\section{Acknowledgements}

The study was part of the European $5 \mathrm{FW}$ project NAT-MAN (QLRT1-CT99-1349); the 
ManFor C.BD project "Managing forests for multiple purposes: carbon, biodiversity and socio-economic wellbeing" (LIFEo9 ENV/IT/000078); EUFORINNO "European Forest Research and Innovation" (Reg. Pot No. 315982); several projects within the Programme group "Forest biology, ecology and technology"; and the Programme group Forest biology, ecology and technology (0404-501), which is financed by the Ministry of Education, Science and Sport, Republic of Slovenia.

\section{References}

Allen RG, Pereira LS, Raes D, Smith M (1998). Crop evapotranspiration. Guidelines for computing crop water requirements. FAO irrigation and drainage paper no. 65, FAO, Rome, Italy, pp. 300. [online] URL: http://appgeodb.nancy. inra.fr/biljou/pdf/Allen_FAO1998.pdf

Anderegg LDL, Anderegg WRL, Abatzoglou J, Hausladen AM, Berry JA (2013a). Drought characteristics role in widespread aspen forest mortality across Colorado, USA. Global Change Biology 19: 1526-1537. - doi: 10.1111/gcb.12146

Anderegg LDL, Anderegg WRL, Berry JA (2013b). Not all droughts are created equal: translating meteorological drought into woody plant mortality. Tree Physiology 33: 701-712. - doi: 10.1093/ treephys/tpto44

Bergès L, Balandier $P$ (2010). Revisiting the use of soil water budget assessment to predict site productivity of sessile oak (Quercus petraea Liebl.) in the perspective of climate change. European Journal of Forest Research 129: 199208. - doi: 10.1007/s10342-009-0315-1

Bertini G, Amoriello T, Fabbio G, Piovosi M (2011). Forest growth and climate change: evidences from the ICP-Forests intensive monitoring in Italy. iForest 4: 262-267. - doi: 10.3832/iforo596004

Bréda N, Huc R, Dreyer E, Granier A (2006). Temperate forest trees and stands under severe drought: a review of ecophysiological responses, adaptation processes and long-term consequences. Annals of Forest Science 63: 625-644. - doi: 10.1051/forest:2006042

Briceno-Elizondo E, Garcia-Gonzalo J, Peltola H, Matala J, Kellomaki S (2006). Sensitivity of growth of Scots pine, Norway spruce and silver birch to climate change and forest management in boreal conditions. Forest Ecology and Management 232: 152-167. - doi: 10.1016/j.for eco.2006.05.062

Cermák J, Kucera J, Nadezhdina N (2004). Sap flow measurements with some thermodynamic methods, flow integration within trees and scaling up from sample trees to entire forest stands. Trees 18 (5): 529-546. - doi: 10.1007/ s00468-004-0339-6

Cermák J, Matyssek R, Kucera J (1993). Rapid response of large, drought-stressed beech trees to irrigation. Tree Physiology 12: 281-290. doi: 10.1093/treephys/12.3.281

Cermák J, Ulehla J, Kučera J, Penka M (1982). Sap flow rate and transpiration dynamics in the full-grown oak (Quercus robur L.) in floodplain forest exposed to seasonal floods as related to potential evapotranspiration and tree dimensions. Biologia Plantarum (Praha) 24: 446-460. doi: $10.1007 / B F 02880444$
Cienciala E, Eckersten H, Lindroth A, Hällgren J-E (1994). Simulated and measured water uptake by Picea abies under non-limiting soil water conditions. Agricultural and Forest Meteorology 71: 147-164. - doi: 10.1016/0168-1923(94)90105-8

Cognard-Plancq A-L, Marc V, Didon-Lescot J-F, Norman M (2001). The role of forest cover on streamflow down sub-Mediterranean mountain watersheds: a modelling approach. Journal of Hydrology 254: 229-243. - doi: 10.1016/S00221694(01)00494-2

Dalsgaard L (2007). Above and belowground gaps-the effects of small canopy opening on throughfall, soil moisture and tree transpiration in Suserup Skov, Denmark. Ecological Bulletins 52: 81-102.

Dirksen C (1999). Soil physics measurements. Catena Verl., Reiskirchen, Germany, pp. 154. [online] URL: http://www.cabdirect.org/abstrac ts/20013083835.html

Dogan S, Berktay A, Singh VP (2012). Comparison of multi-monthly rainfall-based drought severity indices, with application to semi-arid Konya closed basin, Turkey. Journal of Hydrology 470471: 255-268. - doi: 10.1016/j.jhydrol.2012.09.003

Dyer JM (2009). Assessing topographic patterns in moisture use and stress using a water balance approach. Landscape Ecology 24: 391-403. - doi: 10.1007/s10980-008-9316-6

Federer CA (1995). BROOK90 manual: a simulation model for evaporation, soil water and streamflow, version 3.1. USDA Forest Service, Durham, NH, USA, pp. 40.

Federer CA (2002). BROOK90: a simulation model for evaporation, soil water, and streamflow. Version 4.4g. Computer freeware, C. Anthony Federer, Falmouth ME 04105, USA. [online] URL: http://www.ecoshift.net/brook/ brookgo.htm.BROOKgo

Federer CA, Vorosmarthy C, Fekete B (2003). Sensitivity of annual evaporation to soil and root properties in two models of contrasting complexity. Journal of Hydrometeorology 4: 1276-1290. - doi: 10.1175/1525-7541(2003)004 $<1276$ :SOAETS>2.0.CO;2

Ferlan M, Simončič P (2012). Robust and costeffective system for measuring and logging of data on soil water content and soil temperature profile. Agricultural Sciences 3: 865-870. doi: 10.4236/as.2012.36105

Granier A, Biron P, Lemoine D (2000). Water balance, transpiration and canopy conductance in two beech stands. Agricultural and Forest Meteorology 100: 291-308. - doi: 10.1016/S01681923(99)00151-3

Granier A, Breda N, Biron P, Villette S (1999). A lumped water balance model to evaluate duration and intensity of drought constraints in forest stands. Ecological Modelling 116: 269-283. doi: 10.1016/S0304-3800(98)00205-1

Granier A, Loustau D (1994). Measuring and modelling the transpiration of a maritime pine canopy from sap-flow data. Agricultural and Forest Meteorology 71: 61-81. - doi: 10.1016/01 68-1923(94)90100-7

Granier A, Reichstein M, Breda N, Janssens IA, Falge $E$, Ciais $P$, Gruenwald $T$, Aubineth $M$, Berbigier P, Bernhofer C, Buchmann N, Facini $O$, Grassi $G$, Heinesch B, Ilvesniemi $H$, Keronen $P$, Knohl A, Koestner B, Lagergren $F$, Lindroth A, Longdoz B, Loustau D, Mateus J, Montag- nani L, Nys C, Moors E, Papale D, Peiffer M, Pilegaard K, Pita G, Pumpanen J, Rambal S, Rebmann C, Rodrigues A, Seufert G, Tenhunen J, Vesala T, Wang Q (2007). Evidence for soil water control on carbon and water dynamics in European forests during the extremely dry year: 2003. Agricultural and Forest Meteorology 143: 123-145. - doi: 10.1016/j.agrformet.2006. 12.004

Graphpad (2014). GraphPad Prism. Software MacKiev, La Jolla, CA, USA. [online] URL: http:// www.graphpad.com

Gray A, Spies T (1996). Gap size, within-gap position and canopy structure effects on conifer seedling establishment. Journal of Ecology 84: 635-645. - doi: 10.2307/2261327

Gray A, Spies T, Easter M (2002). Microclimatic and soil moisture responses to gap formation in coastal Douglas-fir forests. Canadian Journal of Forest Research 32: 332-343. - doi: 10.1139/ x01-200

Hammel K, Kennel M (2001). Charakterisierung und Analyse der Wasserverfuegbarkeit und des Wasserhaushalts von Waldstandorten in Bayern mit dem Simulationsmodell BROOK9o [Characterization and analysis of water availability and the water balance of forest sites in Bavaria with the simulation model BROOK9o]. Forstliche Forschungsberichte München 185: 135. [in German]

Kolström $M$, Lindner $M$, Vilén T, Maroschek $M$, Seidl R, Lexer MJ, Netherer S, Kremer A, Delzon S, Barbati A, Marchetti M, Corona P (2011). Reviewing the science and implementation of climate change adaptation measures in European forestry. Forests 4: 961-982. - doi: 10.3390/ f2040961

Kutnar L, Kobler A (2011). Prediction of forest vegetation shift due to different climatechange scenarios in Slovenia. Sumarski list 135: 113-126.

Lagergren F, Lindroth A (2002). Transpiration response to soil moisture in pine and spruce trees in Sweden. Agricultural and Forest Meteorology 112: 67-85. - doi: 10.1016/S0168-1923(02) 00060-6

Lebourgeois F, Gomez N, Pinto P, Mérian $P$ (2013). Mixed stands reduce Abies alba treering sensitivity to summer drought in the Vosges mountains, western Europe. Forest Ecology and Management 303: 61-71. - doi: 10.1016/ j.foreco.2013.04.003

Madsen P, Hahn K (2008). Natural regeneration in a beech-dominated forest managed by closeto-nature principles - a gap cutting based experiment. Canadian Journal of Forest Research 38: 1716-1729. - doi: 10.1139/X08-026

Matejka F, Srelcová K, Hurtalová T, Gomoryová E (2007). Modelling transpiration and soil water potential in a spruce primeval forest during dry period. In: Proceedings of the International Scientific Conference on "Bioclimatology and natural hazards". Polana nad Detvou (Slovakia) 1720 Sep 2007. Ceská bioklimatologická společnost, Praha, Czech Republic, pp. 1-7.

Michelot A, Bréda N, Damesin C, Dufrêne E (2012). Differing growth responses to climatic variations and soil water deficits of Fagus sylvatica, Quercus petraea and Pinus sylvestris in a temperate forest. Forest Ecology and Management 265: 161-171. - doi: 10.1016/j.foreco.2011. 
10.024

Mishra AK, Singh VP (2010). A review of drought concepts. Journal of Hydrology 391: 202-216. doi: 10.1016/j.jhydrol.2010.07.012

Nikolova PS, Raspe S, Andersen CP, Mainiero R, Blaschke H, Matyssek R, Häberle K-H (2009). Effects of the extreme drought in 2003 on soil respiration in a mixed forest. European Journal of Forest Research 128: 87-98. - doi: 10.1007/ s10342-008-0218-6

Palahi M, Mavsar R, Gracia C, Birot Y (2008). Mediterranean forests under focus. International Forestry Review 10: 676-688. - doi: 10.1505/ifor.10.4.676

Piedallu C, Gégout J-C, Perez V, Lebourgeois F (2013). Soil water balance performs better than climatic water variables in tree species distribution modelling. Global Ecology and Biogeography 22: 470-482. - doi: 10.1111/geb.12012

Puncer I (1980). Dinarski jelovo-bukovi gozdovi na Kočevskem [Dinaric silver fir - beech forests in Kočevje region]. Razprave 22: 161. [in Czech] Ritter E (2004). The effect of gap formation on soil temperature, soil water, and processes in the nitrogen cycle in temperate beech forests of different management intensities. PhD Thesis, The Royal Veterinary and Agricultural Univerity, Copenhagen, Denmark, pp. 232.

Ritter E, Vesterdal L (2006). Gap formation in Danish beech (Fagus sylvatica) forests of low management intensity: soil moisture and nitrate in soil solution. European Journal of Forest Research 125: 139-150. - doi: 10.1007/s10342005-0077-3

Schwärzel K, Feger K-H, Häntzschel J, Menzer A, Spank U, Clausnitzer F, Köstner B, Bernhofer C (2009a). A novel approach in model-based mapping of soil water conditions at forest sites. Forest Ecology and Management 258: 2163-2174. - doi: 10.1016/j.foreco.2009.03.033

Schwärzel K, Menzer A, Clausnitzer F, Spank U, Haentzschel J, Gruenwald T, Koestner B, Bernhofer C, Feger K-H (2009b). Soil water content measurements deliver reliable estimates of water fluxes: A comparative study in a beech and a spruce stand in the Tharandt forest (Saxony, Germany). Agricultural and Forest Meteorology 149: 1994-2006. - doi: 10.1016/j.agrformet .2009.07.006

Shuttleworth WJ, Wallace JS (1985). Evaporation from sparse crops - an energy combination theory. Quarterly Journal of the Royal Meteorological Society 111 (469): 839-855. - doi: 10.1002/qj. 49711146910

Sohn JA, Gebhardt T, Ammer C, Bauhus J, Häberle K-H, Matyssek R, Grams TEE (2013). Mitigation of drought by thinning: Short-term and long-term effects on growth and physiological performance of Norway spruce (Picea abies). Forest Ecology and Management 308: 188-197. - doi: 10.1016/j.foreco.2013.07.048 Stojanović DB, Kržič A, Matović B, Orlović S, Duputie A, Djurdjević V, Galić Z, Stojnić S (2013). Prediction of the European beech (Fagus sylvatica L.) xeric limit using a regional climate model: an example from southeast Europe. Agricultural and Forest Meteorology 176: 94103. - doi: 10.1016/j.agrformet.2013.03.009

Tegel W, Seim A, Hakelberg D, Hoffmann S, Panev M, Westphal T, Büntgen U (2014). A recent growth increase of European beech (Fagus sylvatica L.) at its Mediterranean distribution limit contradicts drought stress. European Journal of Forest Research 133: 61-71. doi: 10.1007/s10342-013-0737-7

Thompson SA (1999). Hydrology for water management. Balkema, Rotterdam, The Netherlands, pp. 476. [online] URL: http://129.118. 24.171/research/txdot_0-6070/Literature_Archi ve/thompson1999/thompson1999.pdf Urbančič M, Simončič P, Cater M (2005). Impacts of gaps on humus forms in dinaric silver firbeech (Omphalodo-Fagetum) and soil solution quality. Mitteilungen Österreichiches Bodenkdunde Geselschaft 72: 179-187.

Vicente-Serrano SM, Beguería S, López-Moreno JI (2010). A multi-scalar drought index sensitive to global warming: the standardized precipitation evapotranspiration index-SPEI. Journal of Climate 23: 1696-1718. - doi: 10.1175/2009JCLI29 09.1

Vilhar U, Nadezhdina N, Cermak J, Gasparek J, Urbančič $M$, Simončič P (2006a). Meritve in modeliranje transpiracije podsajene bukve $\mathrm{v}$ smrekovem sestoju na Pohorju [Measuring and modeling of the transpiration of underplanted beech in spruce stand on Pohorje]. In: "Splošne ekološke in gozdnogojitvene osnove za podsadnjo bukve (Fagus sylvatica L.) v antropogenih smrekovih sestojih" (Simončič P, Cater M eds). Silva Slovenica,Gozdarski Inštitut Slovenije, Ljubljana, vol. 129, pp. 86-103. [in Slovenian]

Vilhar U, Roenbergar D, Simončič P, Diaci J (2015). Variation in irradiance, soil features and regeneration patterns in experimental forest canopy gaps. Annals of Forest Science 72: 253266. - doi: 10.1007/s13595-014-0424-y

Vilhar U, Simončič P (2012). Water status and drought stress after gap formation in managed and semi-natural silver fir-beech forests. European Journal of Forest Research 131: 1381-1397. doi: 10.1007/s10342-012-0605-x

Vilhar U, Simončič P, Kajfe-Bogataj L, Katzensteiner K, Diaci J (2006b). Mikroklimatske razmere $v$ vrzelih in sestojih dinarskega jelovobukovega gozda [Microclimate conditions in gaps and mature stands of Dinaric silver firbeech forests]. Zbornik gozdarstva in lesarstva 81: 21-36. [in Slovenian]

Vilhar U, Starr M, Urbančič M, Smolej I, Simončič $P$ (2005). Gap evapotranspiration and drainage fluxes in a managed and a virgin dinaric silver fir-beech forest in Slovenia: a modelling study. European Journal of Forest Research 124: 165175. - doi: 10.1007/s10342-005-0067-5

Wellpott A, Imbery F, Schindler D, Mayer $\mathrm{H}$ (2005). Simulation of drought for a Scots pine forest (Pinus sylvestris L.) in the southern upper Rhine plain. Meteorologische Zeitschrift 14: 143-
150. - doi: 10.1127/0941-2948/2005/0015 Zahner R (1967). Refinement in empirical functions for realistic soil-moisture regimes under forest cover. Forest Hydrology. In: Proceedings of the "National Science Foundation Advanced Science Seminar". Pergamon Press, Oxford, Pennsylvania State University, PA, USA, pp. 261273.

Zhou J, Zhang Z, Sun G, Fang X, Zha T, Mcnulty S, Chen J, Jin Y, Noormets A (2013). Response of ecosystem carbon fluxes to drought events in a poplar plantation in Northern China. Forest Ecology and Management 300: 33-42. - doi: 10.1016/j.foreco.2013.01.007

Zierl B (2001). A water balance model to simulate drought in forested ecosystems and its applications to the entire forested area in Switzerland. Journal of Hydrology 242: 115-136. doi: 10.1016/So022-1694(00)00387-5

Zierl B (2004). A simulation study to analyse the relations between crown condition and drought in Switzerland. Forest Ecology and Management 188: 25-38. - doi: 10.1016/j.foreco. 2003.07.019

Zirlewagen D, Von Wilpert K (2001). Modeling water and ion fluxes in a highly structured, mixed-species stand. Forest Ecology and Management 143: 27-37. - doi: 10.1016/S0378-1127 (00)00522-3

\section{Supplementary Material}

Tab. S1 - Values for selected parameters used in the BROOK9o simulation.

Tab. S2 - Linear regression $(y=a+b x)$, correlation coefficients $(r)$, indices of agreement (D), root mean square error (RMSE) and number of measurements $(n)$ between the BROOK9o simulated (y) and measured (x) values for the soil water contents (SWC, $\mathrm{mm}$ ) of the rooting depth (o to $40 \mathrm{~cm}$ ).

Tab. S3 - Linear regression $(y=a+b x)$, correlation coefficients $(r)$, indices of agreement (D), root mean square error (RMSE) and number of measurements $(n)$ between the BROOK9o simulated (y) and the measured ( $\mathrm{x}$ ) throughfall (TF, mm).

Fig. S1 - (a) BROOK9o model fitting and b) BROOK90 model testing: simulated and measured values for soil water contents (SWC, $\mathrm{mm}$ ) of the rooting depth (o to 40 $\mathrm{cm}$ ) for the managed forest, gap, and the old-growth forest during 2001-2007 and the old-growth gap during 2003-2007.

Fig. S2 - Model fitting and testing: simulated and measured values for throughfall TF (mm) for the managed and the oldgrowth forest during 2001-2007.

Link: Vilhar_1630@supploo1.pdf 